\title{
振動流実験によるスリット壁の $C_{D}$ 及び $C_{M}$ の推定と 消波設計への応用
}

\section{1. まえがき}

スリット壁などの透水性の壁を有する消波構造物を設 計する際，その波力及び消波効果を正確に推定すること が要請されるが，基本的な機構である波が透水壁を通過 する時のエネルギー損失量の取り扱いが不明なまま残さ れている.このエネルギー損失量は，一般的に実験によ り係数として取り扱われている. この係数の実験による 決定方法について, 谷本ら（1982）は係数をある関数形 で定め, 実験による反射率に最もよく一致するように決 定している. 角野ら（1986）は，慣性項に関する係数を 理諭的に取り扱っているが，抗力項に関する係数は実験 值の透過率に最もよく一致するように決定している。 た萩原（1985）は, 本研究と同じように波力実験から決 定し, 係数をある関数形で定め平均化して使用してい る.しかしこれらの決定方法は, 透水壁の構造条件であ る空隙率, 壁厭などは取り入れられているが, 水理的条 件である Reynolds 数, Keulegan-Carpenter 数などの影 響については考慮されていない，そこで著者らは，すで に円柱などの 孤立構造物に用いられている Morison 式 を透水壁に応用して透水壁に働く波力から杭力係数 $C_{D}$ 及び質量係数 $C_{M}$ を求め, 背後不透過壁のない学一のス リット壁についてこれらの $C_{D}$ 及び $C_{M}$ を空隙率, 相 対スリット幅, Reynolds 数及び Keulegan-Carpenter 数 で整理してきた（浦島ら，1983）。これまでの波動場の 実験では実流速まで流速の範囲を広げることが出来なか ったので, 本研究では新たに作成した振動流実験装置に よる単一スリット壁などの穾験を行い， $C_{D}$ 及び $C_{M}$ の 特性をより明かにし，スリット壁の設計への応用の問題 点を検討したものである.

\section{2. 突験装置及び方法}

\subsection{2 次元規則波実験}

実験は長さ $19.7 \mathrm{~m}$, 幅 $0.8 \mathrm{~m}$ のペンデュラム式造波 装埴が設置されている両面ガラス張りの水平底の二次元

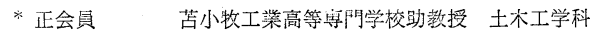

**正会貝 工博 室蘭工業大学教授 工学部建設システム工学科
}

浦 島 三 朗*. 近 藤 俶 郎**

規則波造波水槽を仕切り板により二分した水槽を用い た、その一方にスリット壁を取り付けた波力検出装置を 設置している．波力検出装置はアーム上端部を固定した 片持梁構造でアーム部にストレインゲージを貼付してあ る. 模型として使用したスリット壁はアクリル材を用 い, 空隚率 $\lambda=35 \%$, スリット幅 $s=28 \mathrm{~mm}$, 壁厚 $d w$ $=30 \mathrm{~mm}$ であり, 構造は一枚スリット壁型不透過堤で 背後不透過壁には水槽の末端を使用し, 遊水室幅 $B=$ $66.5 \mathrm{~cm}$ と一定にした。実験は入射波高 $H_{I}=3.5 \sim 13$ $\mathrm{cm}$, 周期 $T=1.2 \sim 20 \mathrm{sec}$ で, 水深 $h=50 \mathrm{~cm}$ 之一定 にして行なった，入・反射波の振幅 $a_{I}, a_{R}$ 及び位相 $\delta_{I}, \delta_{R}$ の決定方法には合田ら（1976）による分離推定法 を用い，またスリット壁前面の水面波形りはスリット 壁前方 $2.5 \mathrm{~cm}$ に取り付けた波高計より測定している.

\section{2 振動流実験}

振動流実験装置は, 図一1 亿示すようなU字管型の装 置を製作した. 水平部の中央水路 $200 \mathrm{~cm}$ の観測部は, 幅 $20 \mathrm{~cm}$, 高さ $20 \mathrm{~cm}$ の矩形断面でアクリル材を使用 して扮り, 駆動部の回転運動をピストンの水平運動に变 換し, 観測水路内に一定の振動流を発生させるものであ る.両方のタンク部の端は解放されて大気圧の状態にな っている. ピストン運動は周期約 $1.0 \sim 4.0 \mathrm{sec}$, 振幅 70 〜230 mm の範囲で変化させることが出来る. 実験は, 模型に単一スリット壁を用い, 模型の下部を三分力計に 取り付けスリット壁に働く水平力, 鉛直力及びモーメン

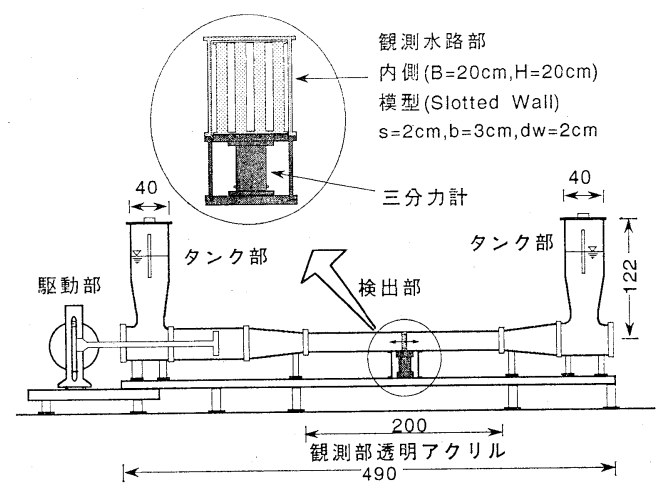

図-1 振動流実験装置（単位：cm) 
トを測定した．両側のタンク部に波高計を設置し，その 水位も同時に測定している. スリット壁は, 幅 $b=30$ $\mathrm{mm}$, 厚さ $d w=20 \mathrm{~mm}$, 高さ $20 \mathrm{~cm}$ の角柱を空吵率 $\lambda=40 \%$ ，スリット幅 $s=20 \mathrm{~mm}$ で配置したものを用い ている.

\section{3 解析方法}

波力算定式はスリット壁に作用する全水平力 $F_{T}(t)$ は，揚力が働かないものとすると Morison の提案した 構造物背後の渦によって生ずる力の抗力 $F_{D}(t)$ と，圧 力勾配によって生ずる力ならびに構造物の存在によって 生ずる力の慣性力 $F_{I}(t)$ の線形和として式 (1) で表わ される。

$$
\begin{aligned}
F_{T}(t) & =F_{D}(t)+F_{I}(t)=C_{D} \cdot f_{D}(t)+C_{M} \cdot f_{I}(t) \\
& =C_{D} \rho \int \frac{u|u|}{2} d A+C_{M} \rho \int \dot{u} d V \quad \ldots .
\end{aligned}
$$

ここで, $\rho$ : 水の密度, $d A$ : 投影微 小面積, $d V:$ 実質 部の微小体積である.

抗力係数 $C_{D}(t)$ 及び質量係数 $C_{M}(t)$ を時間の 関数 として考光，実湘の水平力 $F_{T}(t)$ と各時刻 $t$ での式

(1) で求められる理論の水平力 $F_{C}(t)$ が一致するよ うに決定する Al-Kazily の手法を模して $C_{D}(t), C_{M}(t)$ を求めると式（2），(3) となる.

$$
\begin{aligned}
& C_{D}\left(t+\frac{\Delta t}{2}\right)=\frac{F_{T}(t+\Delta t) \cdot f_{I}(t)-F_{T}(t) \cdot f_{I}(t+\Delta t)}{f_{D}(t+\Delta t) \cdot f_{I}(t)-f_{D}(t) \cdot f_{I}(t+\Delta t)} \\
& C_{M}\left(t+\frac{\Delta t}{2}\right)=\frac{F_{T}(t+\Delta t) \cdot f_{D}(t)-F_{T}(t) \cdot f_{D}(t+\Delta t)}{f_{D}(t+\Delta t) \cdot f_{I}(t)-f_{D}(t) \cdot f_{I}(t+\Delta t)}
\end{aligned}
$$

ここで, $\Delta t:$ 測定時間間隔である.

また抗力係数 $C_{D}$ 及び質量係数 $C_{M}$ を時間に対して 一定と考光, 実測と理論の水平力の差が最小になるよう に $C_{D}, C_{M}$ を決定する最小自乗法による方法を用いる と式（4)，（5）となる.

$$
\begin{aligned}
& C_{D}=\frac{\left|\begin{array}{cc}
\sum F_{T}(t) \cdot f_{D}(t) & \sum f_{D}(t) \cdot f_{I}(t) \\
\sum F_{T}(t) \cdot f_{I}(t) & \sum f_{I}(t)^{2}
\end{array}\right|}{\left|\begin{array}{cc}
\sum f_{D}(t)^{2} & \sum f_{D}(t) \cdot f_{I}(t) \\
\sum f_{D}(t) \cdot f_{I}(t) & \sum f_{I}(t)^{2}
\end{array}\right|} \\
& C_{M}=\frac{\left|\begin{array}{cc}
\sum f_{D}(t)^{2} & \sum F_{T}(t) \cdot f_{D}(t) \\
\sum f_{D}(t) \cdot f_{I}(t) & \sum F_{T}(t) \cdot f_{I}(t)
\end{array}\right|}{\left|\begin{array}{cc}
\sum f_{D}(t)^{2} & \sum f_{D}(t) \cdot f_{I}(t) \\
\sum f_{D}(t) \cdot f_{I}(t) & \sum f_{I}(t)^{2}
\end{array}\right|}
\end{aligned}
$$

規則波実験に执いて，スリット壁では円柱等の孤立構造 物とは異なり, 反射波を無視することが出来ないので, 式（1）中の水平水粒子速度 $u$ 及び加速度 $\dot{u}$ 㳊微小振 幅波理論の部分重複波で考えると式（6)，（7）とな る.

$$
u=a_{I} \sigma \frac{\cosh k(h+y)}{\sinh k h} \cos \left(k x-\sigma t+\delta_{I}\right)
$$

$$
\begin{aligned}
& -a_{R} \sigma \frac{\cosh k(h+y)}{\sinh k h} \cos \left(k x+\sigma t+\delta_{R}\right) \\
& \dot{u}=a_{I} \sigma^{2} \frac{\cosh k(h+y)}{\sinh k h} \sin \left(k x-\sigma t+\delta_{I}\right) \\
& +a_{R} \sigma^{2} \frac{\cosh h(h+y)}{\sinh k h} \sin \left(k x+\sigma t+\delta_{R}\right)
\end{aligned}
$$

ここで $k:$ 波数 $(=2 \pi / L), \sigma$ : 角周波数 $(=2 \pi / T)$, $L:$ 波長である.

振動流実験では, 水路内の水粒子の軌跡 $x$, 水粒子速 度 $u$ 及び加速度 $\dot{u}$ は各場所で一様とすると時間 $t$ の関 数として式（8）で定義される.

$x=R \sin \sigma t, u=R \sigma \cos \sigma t, \quad \dot{u}=-R \sigma^{2} \sin \sigma t$

ここで, $R$ : 観測水路部の水粒子の移動半径である.

な和抗力係数 $C_{D}$, 質量係数 $C_{M}$ は Reynolds 数及び Keulegan-Carpenter 数の関数として表示されることが 多い. 水平水粒子速度は一般に最大值が用いられるが, ここでは定常流実験との連続性を考慮して，水深方向及 び周期内で平均した水平水粒子速度 $u_{\text {mean }}$ を使用して いる. Reynolds 数及び Keulegan-Carpenter 数は式 （9）で定義することとした。

$$
R E=\frac{u_{\text {mann }} \cdot s}{\nu}, \quad \text { K.C. }=\frac{u_{\text {masn }} \cdot T}{d_{w}}
$$

ここで，ン：動粘性係数を表わす。

また時刻 $t=0$ の決定は，規則波実験に和いてはスり ット壁前面の波形記録 ク, 振動流実験に执いてはタンク 部の水位記録から決定している.

\section{3. 実験結果及び考察}

\section{1 反 射率}

単一スリット壁から求めた $C_{D}$ 及び $C_{M}$ を使用して, スリットケーソンの反射率 $K_{R}$ を計算し, 実験 值と比 較したものを図一2，3 に示す． $K_{R}$ の計算には著者の 一人（近藤，1981）によって提案されている理論を用い ている.これらの計算値は, 遊水室幅 $B$ と波長 $L$ の 比 $B / L$ が 0 及び 0.5 ではスリット壁での水平水粒子 速度が 0 となり $K_{R}=1$ となり, $B / L=0.25$ 付近では 水平水粒子速度が最大となるため $K_{R}$ は極小值をとる. また $H_{I} / L$ が小さい核ど $K_{R}$ は小さくなり，周期の長 い㴗ど $K_{R}$ は小さくなる。これらは今までの研究と同様 の結果を得ており，単一スリット壁の $C_{D}$ 及び $C_{M}$ を スリットケーソンの消波設計に使用できるものと考えら れる.しかし，極小付近の $K_{R}$ は実験值よりも小さくな っている.これは大きな流速場に和いては使用した単一 スリット壁の $C_{D}$ 及び $C_{M}$ が実際よりも大きく見積も られているためと考えられる。 


\section{2 波高分布}

図一4 は，周期叔よび入射波高 を一定にし, 遊水室幅を変化させ た時の波高分布図でめる。 $X$ は, スリットケーソンの背後不透過壁 を $X=0$ として定めている. 波高 $H$ は，有効測定時間内で平均した ものを用いている．各波高分布図 は腹と節をもつ部分重複波を示し ている．波の節は，背後不透過壁 から波長のほぼ1/4の所に見られ， スリット壁の位置によってそれほ ど変化していない。これは，空吵 率 $35 \%$, 壁厚 $30 \mathrm{~mm}$ のスリッ ト壁では，スリット壁による反射

波が小さく，背後不透過壁による反射波によって部分重 複波が形成されるためと考えられる，なた，スリット壁 前後の波高の差が大きいことが認められる．単一の縦ス リット壁の水粒子速度の実験（浦島ら，1984）に叔いて も，スリット壁前後の水粒子速度は異なり，これらのこ とが反射率の実験に和ける極小值付近の反射率が実験值 と計算値で異なる1つの要因となっているものと思われ る。

図一5 は，周期扣よび遊水室幅を一定にして，入射波 高を变化させた時の波高分布図である，各波高分布は入 射波高を变化させても，注涪同じ分布状態を示す，スり ット壁前後の $H / H_{I}$ の差は，入射波高が小さく，反射 率が大きい波ほど大きいことが認められる。李た節の部 分の波形次次節のスペクトル解析でも明らかなように, 細く割れたよらな形を示し，高調波成分の影響が特に大 きく出ている.

\section{3 スペクトル解析}

図一6 は，スリットケーソンに劣ける実験波のパワー スペクトルを表したものであり，（a）～（f）は，分離 推定法で求めた入射波と反射波の振幅のパワースペクト ル，（g)〜 ( j ) は水路の各位置に和ける波形のパワー スペクトルを各周波数で表したものである. スペクトル 解析を行うためにサンプリングした記録時間が，有効測 定時間の関係で周期の 4 倍の $6.0 \sim 8.0 \mathrm{sec}$ と非常に短 いため，規則波であることを明示するような鋭い線スペ クトルにはなっていないけれども, 造波機に入力した基 本周波数 $f_{0}$ の整数倍の周波数付近で, 明瞭なピークが 認められる。

入射波のパワースペクトルは，入射波高を一定にし遊 水室幅を変化させた（a），(b) ではほぼ同一の值を示 す.また, 遊水室幅を一定にし入射波高を変化させた (b)，（c），(d) に执いてもほぼ同一の值を示してい る.しかし，周期を変化させた（e），（f）を見ると 3

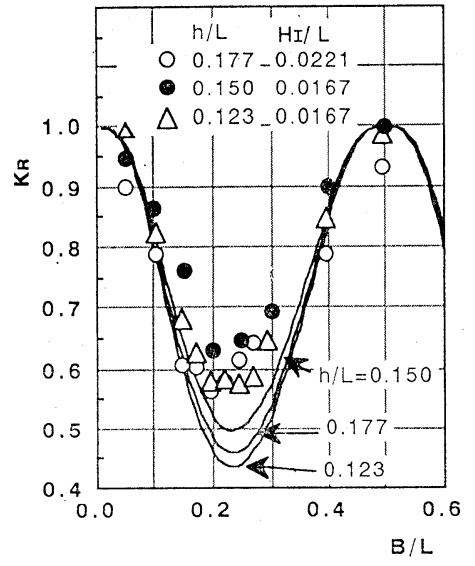

図一3 周期による $K_{R}$ の变化

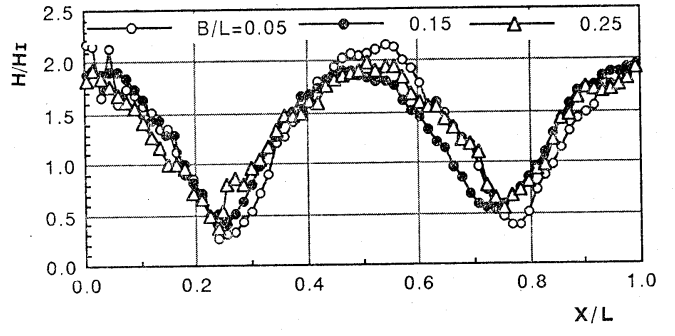

図一4 波高分布 $\left(h / L=0.150, H_{I} / L=0.0123\right)$

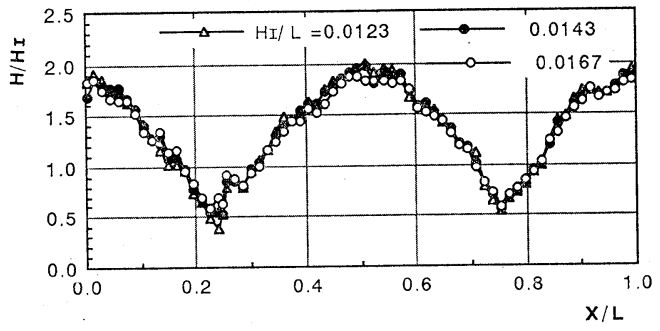

図一5 波高分布 $(B / L=0.25, h / L=0.150)$

倍の周波数付近で異なった傾向を示している.これらの ことより入射波のパワースペクトルは，造波水路及び造 波機の特性によって決まるもので，高次の成分波は周期 によって影響されるが，入射波高及び遊水室幅の変化に よる影響は小さいように思われる。

（a）（d）の反射波のパワースペクトルを見てみる と, ほ注全体的に基本周波数及びその 2 倍周波数付近に おいて卓越している。 また，入射波高の小さい（a)，

（b）に拈いては入射波より反射波のパワースペクトル の方が小さいが，入射波高の大きな状態の ( c ), (d) に おいては，2 倍周波数付近で入射波より反射波のパワー スペクトルの方が大きい、これは，波がスリット壁を透 過あるいは反射する際に発生する高次の成分波は，入射 
波高が大きくなると顕著に表れるものと思われる. 同じ ような傾向が入射波高が大きい（e）にも見られる.

図の $(g) \sim(j)$ のパワースペクトルの測定位置は,
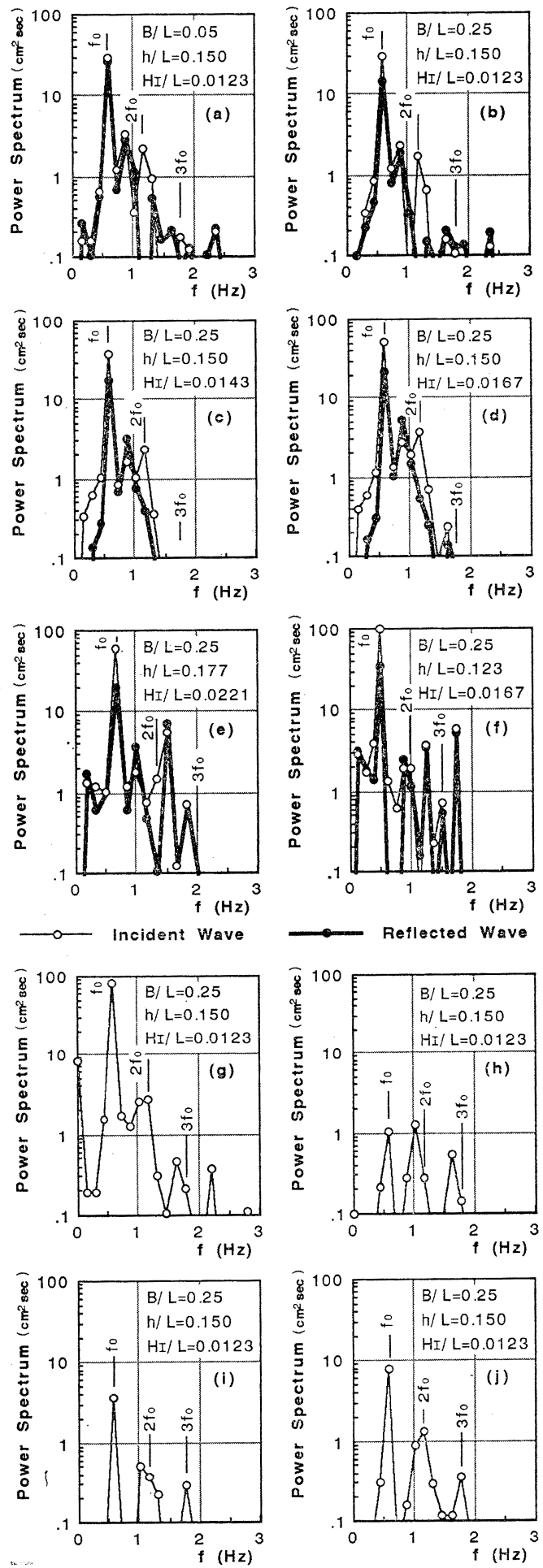

図一6 スリットケーソンのパワースペクトル
背後不透過壁より $1.5 \mathrm{~cm}$ ，スリット壁後方 $1.0 \mathrm{~cm}$ ， ス リット壁前方 $1.0 \mathrm{~cm}$ 及び部分重複波の節の付近であ る. 各場所でのパワースペクトルは基本周波数以外に 2 倍及び 3 倍周波数付近までが卓越している. 背後不透過 壁の $(\mathrm{g})$ では，0次の周波数についても卓越している が，これは波が不透過壁で上打ら上げられ，静水面 で上下対称な形をしていないためである、スリット壁前 後では前方の方が基本周波数の成分波が大きく出てい る.

\section{4 振動流実験}

振動流の実験結果を時系列で表した例を図一7に示 す. 水粒子の軌跡 $x$ はタンク部の水位より求められて いるが，全体的に正弦波の動きと非常に良く一致してい る. 実測の水平力 $F_{T}$ も正負の方向で対称的な大きさ及 び形を示している。なた同時に測定した曲げニーメント は $F_{T}$ に比例し， $F_{T}$ の合力も浪断面中央に作用して いることが確認されている、これらのことより本装置は 断面に刘してほぼ一樣な振動流が発告しているものと考 えられる.

最小自乗法で求めた抗力係数 $C_{D}$ 及び質量係数 $C_{A I}$ を 使用して求めた理論の水平力 $F_{C}$ と実測の水平力 $F_{T}$ は 非常に良く各実験条件に就いて一致している，波動実騟 に执いては，算定する水粒子速度及び加速度が正負対称

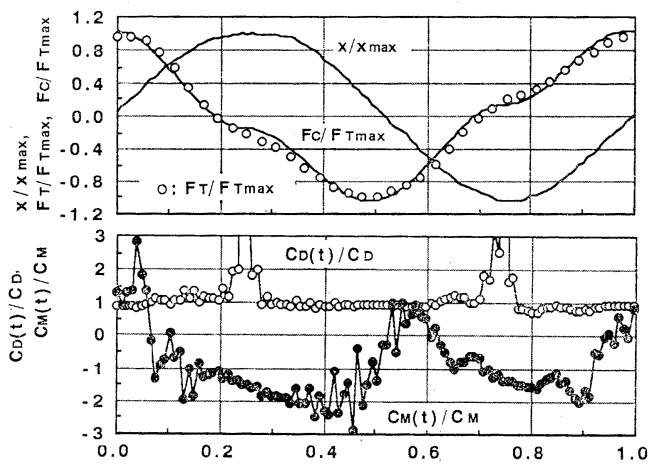

(a) $\mathrm{RE}=4603, \mathrm{KC}=23$

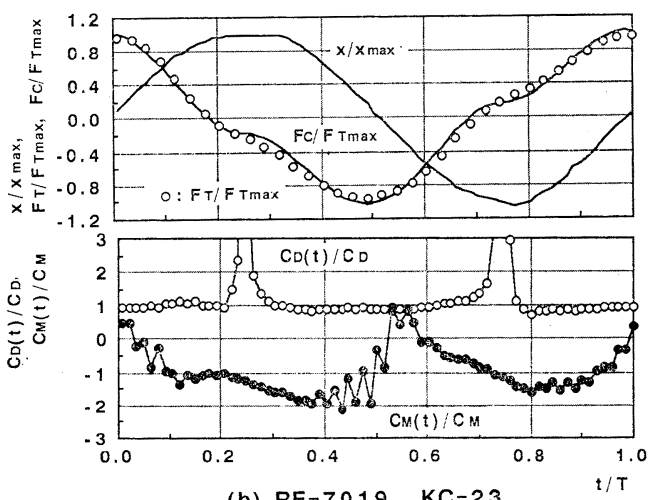

(b) $R E=7019, K C=23$

図一7 実験結果の時系列 


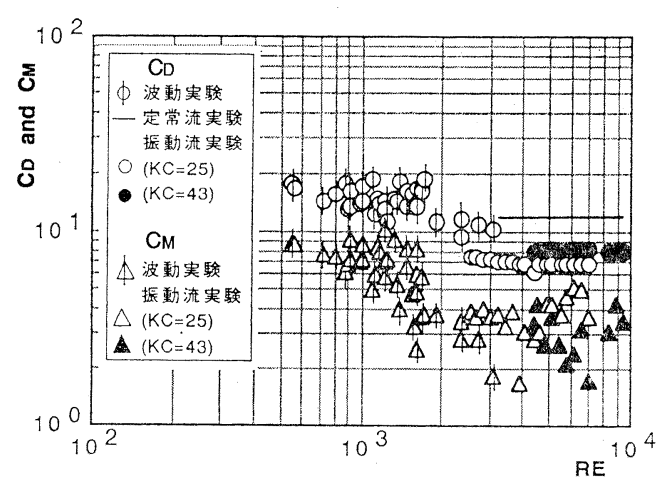

図一8 スリット壁の $C_{D}$ 及び $C_{M}$

なので，理論波力は正負対称となる。しかし，実測波力 は正負対称とはならなく，理論波力とに誤差を生じてい た (浦島ら, 1983).

Al-Kazily の方法で求められた抗力保数 $C_{D}(t)$ 及び 質量係数 $C_{M}(t)$ を最小自乘法で求めた值 $C_{D}, C_{M}$ 之の 比を图一7に示している．抗力係数汸波陲実験と同じよ らに, 水粒子速度が 0 になる $t / T=0.25,0.75$ 付近で 大变な変動を示す. しかしそれ以外のところでは一定と なって和り, 最小自乘法で求めた值と㴒添一致してい る. このことより抗力倸数は時間によらず周期内で一定 值と考兄られる. 質量俰数沉いては, 波動実験に括い て水粒子加速度が最も大きいところで最小自乘法で求め た值と近い値で一致していた。しかし今回の振動流実験 では時間による変動が大きく，また最小自乗法で求めた 値との関係は特に見られなく、今後の検討の余地が残さ れている.

最小自乗法で求めた抗力係数及び質量係数を Reynolds 数で整理したものを図一8 亿示す．抗力係数注この範围 の Reynolds 数では泳ぼ一定の值を示している. しかし Keulegan-Carpenter 数によって変化して括り, 孤立構 造物と同じょうな傾向を示すことが考兄られる。質量係 数については多少のバラッキはあるが, Reynolds 数や Keulegan-Carpenter 数によって変化している傾向も見 られる. 図中には $\lambda=35 \%$ のスリット壁の波動実験及 び定常流実験の結果もあわせて示しているが，比皎的良 く連続している.

\section{4. あとがき}

規則波実験に括いて， $K_{R}$ の計算値は極小値以外は実 験値とほ添同一の值を示し, 本方法による $C_{D}$ 及び $C_{M}$ をエネルギー損失量を表す係数として用いることの妥当 性が証明された，波高分布より位相のズレは入射波高に よって変化せず，遊水室幅によって異なることがわかっ た. またスペクトル解析によって基本周期以外に 2 次, 3 次成分波が発生していることが認めら礼る。スリット ケーソンの波力実験による $C_{D}$ 及び $C_{M}$ 怯，基本周期以 外飞 2 次, 3 次成分波を考慮しても, 単一スリット壁の

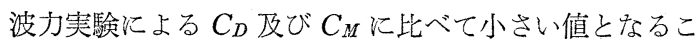
とがわかった。

振動流実験に和いて $C_{D}$ は時間によらず一定であり， $C_{M}$ はもう少し検討の必要がある. しかし周期内で一定 として求めた $C_{\nu}$ 及び $C_{M}$ を使用して水平力を計算する と実験值と活㜔完全に一致する。また $C_{D}$ 及び $C_{M}$ が Reynolds 数のみではなく更に Keulegan-Carpenter 数に よっても変化することが認められ，波動実験及び定常流 実験との関係もより明らかになった。本研究の $C_{D}$ 及び $C_{M}$ は円柱㐫どの孤立構造物の值より大きな值を示す が，これ惊水路内の平均流速を用いているためで㐫り， スリット部を通過する実流速で考光ると円柱などと同程 度の值となり, 妥当な結果である。

\section{参 考 文 献}

浦島三朗・石塚耕一・近藤俶郎 (1983)：縦スリット壁に作用す る波力関する基礎的研究，第30回海岸工学講演会論文集, pp. 337-341.

浦島三朗・石塚耕一・近藤椒郎 (1984)：スリッ卜壁周辺の波高 及び水平最大水粒子速度について, 第 39 回土木学会年次学 術講演会講演概要集第 2 部, pp. 339-340.

角野昇八・小田一紀・村本哲二・芳田利春 (1986)：複素係数の blockage coef. を尊入した漸近展開接合法, 第 33 回海岸工 学講演会論文集, pp. 407-411.

合田良実・鈴木康正・岸良安治・菊地 治 (1976)：不規則波実 験飞打ける入,反射波の分離推定法, 港湾技研資料, No. 248.

近藤叔郎 (1981): 直立消波構造物の水理的特性, 水工学シリ一 ズ, $81-\mathrm{B}-1$.

近藤俶郎－竹田英章 (1983)：消波構造物，森北出版， 279 p.

谷本勝利・吉本靖俊 (1982)：直立消波ケーソンの反射率に関す る理論及び实験的研究, 港掯技術研究所報告, 第 21 巻第 3 号, pp. 43-77.

萩原運弘 (1985): 多重円筒列型防波堤の反射率・透過率の解析 と諸要因の影響, 土木学会論文集, 第 363 号/ II-4, 185194. 